\title{
Internetowe głosowanie $w$ E-stonii na przykładzie wyborów w latach 2005-2009
}

\section{Wprowadzenie}

W spółcześnie - w obliczu tzw. rewolucji informacyjnej ${ }^{1}$ - nie ma wątpliwości, że demokracja ulega poważnym i bardzo widocznym przeobrażeniom. W konsekwencji tych zmian od lat 80-90-tych minionego wieku obserwuje się ewolucję funkcjonowania współczesnych państw, ich systemów politycznych i społeczeństw. Przeobrażenia te są rezultatem między innymi coraz szerszego zastosowania nowych technologii komunikacyjnych i informacyjnych (ICT - Information and Communication Technologies). Warto zatem zauważyć, iż wraz z postępującym na świecie rozwojem technik telekomunikacyjnych, informatycznych czy środków masowego przekazu, epoka cywilizacji przemysłowej zaczęła ustępować, a precyzyjniej - już zdołała ustąpić - miejsca tzw. poprzemysłowej cywilizacji informacyjnej.

Należy zauważyć, iż w opiniach wielu teoretyków i badaczy demokratycznej formy sprawowania władzy obecne jest przekonanie, że tak zwane rządy ludu początków XXI wieku znajdują się w nienajlepszej kondycji. Mówi się często o tzw. kryzysie demokracji, którego przejawem są m.in. kryzys partii politycznej, kryzys zaufania do polityków, kryzys związany z poziomem uczestnictwa obywateli w procedurach wyborczych, którego symbolem jest niska frekwencja wyborcza w elekcjach państwowych ${ }^{2}$. Ten stan rzeczy potwierdza Maria Nowina Konopka, która twierdzi, iż $w$ zwiqzku z obserwowanym $w$ państwach Europy od poczatku lat 80. XX wieku, w Polsce zaś od połowy lat 90., spadkiem zaufania do rzqdów i parlamentów oraz wraz z rozwojem nowoczesnych technologii informacyjnych i komunikacyjnych, coraz częściej pojawiaja się opinie postulujace powrót do bezpośredniej formy rzadów ${ }^{3}$.

\footnotetext{
${ }^{1}$ Robert O. Keohane i Joseph Nye termin ten łączą z gwałtownym rozwojem technologicznym w zakresie komputerów, procesu komunikacji i oprogramowania, związanymi ze znacznym obniżeniem kosztów przetwarzania i przekazywania informacji. Tym, co wyróżnia rewolucję informacyjna jest olbrzymia redukcja kosztów transmisji danych; R. O. Keohane, J. Nye jr, Power and Interdependence in the Information Age, w: Democracy.com? Governance in a Networked World, red. E. Kamarck, J. Nye Jr, Hollis 1999, s. 200. Nowy etap rewolucji naukowo-technicznej, z którym mamy do czynienia obecnie, określany jest często jako ,piąta fala cyklu Kondratieffa” lub „trzecia fala Toflera". Etap ten stanowi okres rewolucji informacyjnej, związany z gwałtownym przyspieszeniem postępu technicznego i połączeniem w jedną z kilku istniejących dotychczas technologii określanych jako technologie informacyjne. Okres ten przybliżył świat do każdego człowieka i każdego człowieka do świata i połączył wszystkich w jedną globalną sieć informacji, handlu, finansów i kultury. D. Łapuszek, Rola postepu technicznego w procesie globalizacji, „Zarządzanie zmianami”, Biuletyn POU, maj 2007, http:/www.wsz-pou.edu.pl/biuletyn/?strona=biul_globlap\&nr $=6 \& \mathrm{p}=, 18.06 .2010$.

${ }^{2}$ A. Żukowski, Dylematy demokracji XXI wieku. Wybory rytualne czy balotaż partycypacyjny?, ,Przegląd Politologiczny" 2005, nr 2, s. 77.

${ }^{3}$ M. Nowina Konopka, Społeczeństwo informacyjne a teorie demokracji, w: Społeczeństwo informacyjne. Istota. Rozwój. Wyzwania, red. M. Witkowska, K. Cholawa-Sosnowska, Warszawa 2006, s. 82.
} 
Oprócz tego Nowina Konopka zwraca uwagę na wykorzystanie „,nowych” sposobów uczestnictwa w procedurach wyborczych - np. na głosowanie elektroniczne, którego zastosowanie w Estonii jest przedmiotem niniejszego tekstu. Bez wątpienia można stwierdzić, iż wykorzystanie elektronicznych technik w sprawowaniu demokratycznej władzy stanowi swoistą rewolucję, która ze względu na różne możliwości poszczególnych państw (związane z upowszechnianiem nowych technologii, np. z zasięgiem infrastruktury internetowej, dostępnością do Internetu wśród społeczeństwa) może rozłożyć się na wiele lat.

Tak zwane nowe media powszechne są w życiu politycznym już co najmniej kilkanaście lat. Należy zwrócić uwagę, iż w wyniku ich zastosowania fundamentalne zasady demokracji wydają się nabierać innej, nowej jakości. Zasady demokratyczne (suwerenność narodu, trójpodział władzy, pluralizm, konstytucjonalizm czy praworządność) zaczynają funkcjonować w nieco, wydaje się, szerszym wymiarze. Oprócz tradycyjnych form realizacji tych zasad pojawiają się nowe rozwiązania - oparte na nowoczesnych technologiach. Zasada suwerenności na przykład, urzeczywistniana jest poprzez fakt funkcjonowania instytucji demokracji przedstawicielskiej oraz bezpośredniej, które z kolei znajdują swój wyraz w wyborach, referendach czy innych formach zbiorowego podejmowania decyzji na szczeblu krajowym czy lokalnym. To między innymi za pomocą tych form elekcji wprowadzana w życie jest zasada zwierzchnictwa narodu.

Obecnie obserwuje się coraz częstszą tendencję, polegającą na tym, że w wielu państwach Europy i świata wdraża się różne nowoczesne formy oddawania głosów, do których zaliczyć należy przede wszystkim głosowanie elektroniczne za pośrednictwem np. Internetu czy telefonii komórkowej ${ }^{4}$. W opinii zwolenników wykorzystania ICT - dzisiejsza cywilizacja stoi obecnie w obliczu ery demokracji elektronicznej, która stanowi tę nową formę sprawowania władzy - opartą właśnie na wykorzystaniu narzędzi teleinformatycznych ${ }^{5}$.

\section{Elektroniczna demokracja i elektroniczne głosowanie}

Koncept elektronicznej (lub inaczej - cyfrowej) demokracji wiąże się z wieloma podejściami i analizami odpowiadającymi na pytanie o to, jak nowe media informacyjne i komunikacyjne wpływają na nowoczesne demokracje i jakich możliwości tym państwom dostarczają. Zainteresowanie wykorzystaniem technologii informacyjno-komunikacyjnych w celu rozwoju demokracji elektronicznej po raz pierwszy pojawiło się w roku 1970 w Stanach Zjednoczonych. Impulsem dla rozwoju idei i pilotażowych projektów był wzrost znaczenia ICT oraz coraz większe obawy o stan amerykańskiego systemu politycznego [związane ze spadkiem liczby wyborców uczestniczących w życiu politycznym (głównie w głosowaniach) oraz wysokim poziomem cynizmu i brakiem zaufania społecznego].

Dyskusje na temat demokracji elektronicznej na ogół skupiają się na trzech głównych koncepcjach: na demokracji bezpośredniej lub plebiscytarnej, na demokracji reprezentatywnej i na komunitarianizmie. Każdy z tych konceptów demokracji akcentuje różny poziom wykorzystania i regulacji dotyczących nowych technologii.

\footnotetext{
${ }^{4} \mathrm{O}$ tych formach głosowania traktuje dalsza część niniejszego tekstu.

${ }^{5}$ S. London, Teledemocracy vs. Deliberative Democracy: A Comparative Look at Two Models of Public Talk, „Journal of Interpersonal Computing and Technology” 1995, vol. 3, nr 2, s. 33-55, http://www.scottlondon.com/reports/tele.html, 15.05.2006.
} 
Zwolennicy demokracji plebiscytarnej jako jedni z pierwszych pisali o rozwoju projektów demokracji elektronicznej (np. A. Toffler, T. Becker). Potencjał nowych technologii widzieli oni przede wszystkim w tym, iż eliminują one ograniczenia czasu i przestrzeni, które zwykle utrudniają funkcjonowanie demokracji bezpośredniej. Dzięki ICT dostarczane są informacje, przetwarzane dane, ułatwiona jest komunikacja, co pozwala nieograniczonej liczbie osób na jednoczesny udziału w debacie i głosowaniu.

ICT mogą istniejące modele demokracji przedstawicielskiej uczynić bardziej elastycznymi. Ten pogląd intensywnie forsują amerykańscy pluraliści, oczekujący iż nowe technologie mogą stworzyć lepsze warunki do konkurowania ze sobą różnych grup interesów. Z tego punktu widzenia, oczekuje się, że technologie informacyjno-komunikacyjne wpłyną na większą ilość i dostępność informacji dla różnorodnych grup, które będą mogły realizować bardziej zróżnicowany wachlarz celów. Ponadto, nowe technologie umożliwiają dostęp do informacji, a także zapewniają środki do ich przechowywania i przetwarzania w sposób stosunkowo tani, szybki i skuteczny. Takie korzyści dotychczas dostępne były jedynie dla dużych i bogatych organizacji ${ }^{6}$.

Trzeci wymiar związany jest z komunitarianizmem lub tzw. silnq demokracja ${ }^{7}$. Obywatelstwo i dobro wspólne stanowią najważniejsze elementy komuntarianizmu. Warto w tym miejscu nadmienić, iż świadome uczestnictwo w procesach podejmowania decyzji państwowych wymaga od obywateli nie tylko zainteresowania i motywacji do zaangażowania się w życie polityczne, ale także wiedzy o nim. Kwestia ta jest tym bardziej ważna, iż we współczesnych społeczeństwach obserwuje się coraz większą liczbę coraz bardziej skomplikowanych spraw wymagających decyzji, a proces ich podejmowania staje się coraz trudniejszy $^{8}$. Dlatego też coraz częstsze są postulaty zwolenników komunitarianizmu dotyczące gruntowniejszej edukacji obywatelskiej ${ }^{9}$. Komutarianizm bowiem proponuje demokracje bardziej bezpośrednia (częstsze wybory, więcej stanowisk obsadzanych $w$ drodze wyborów, objęcie niq nowych sfer życia) i uczestniczqca (odwotywanie źle ocenianych przedstawicieli, korzystanie z inicjatywy dotyczacej referendum, uczestniczenie $w$ samorzadach lokalnych $i$ w miejscu pracy). Oprócz tego coraz bardziej powszechne sq sugestie wykorzystania nowych technologii, które prócz edukacji umożliwilyby większe zaangażowanie obywateli w sprawowaniu władzy. Mogłoby to wpłynać na wzrost poziomu kultury politycznej w państwach oraz przełożyć się na większe zaangażowanie (partycypacje) w procesy decyzyjne ${ }^{10}$. Można zatem stwierdzić, iż nowe technologie informacyjne i komunikacyjne są szczególnie przydatne z punktu widzenia zwolenników komunitarianizmu. Dzięki ICT możliwe stają się bardziej bezpośrednie formy głosowania, a także opiniowanie różnorodnych projektów, co stanowi jedno z wyzwań programu komunitarianistów (krytyka modeli plebiscytarnych). Technologie

\footnotetext{
${ }^{6}$ I. Horrocks, L. Pratchett, Democracy and New Technology, Electronic Democracy: Central Themes and Issues, http://www.clubofamsterdam.com/contentarticles/Democracy\%20and\%20New\%20Technology.pdf, 01.11.2010.

${ }^{7}$ Pojęcie silnej (mocnej) demokracji wprowadza Benjamin R. Barber w swojej książce Strong Democracy. Participatory Politics for a New Age. Barber przypisuje silnej demokracji szereg cnót, zaliczając do nich aktywność, zaangażowanie, obowiązek, które są praktykowane przez wspólny namysł i pracę. Oparcie silnej demokracji m.in. na uczestnictwie, obywatelskości czy dobrze publicznym zakłada, że obywatele nie tylko postrzegają je jako wartość, lecz także są zdolni do dokonywania autonomicznych i odpowiedzialnych wyborów. Samo zaś uczestniczenie w procesie decyzyjnym wynika z woli i przekonania obywateli; B. R. Barber, Strong Democracy Participatory Politics for a New Age, Berkeley-Los Angeles-London 2003, s. 133.

${ }^{8}$ P. Śpiewak, Obietnice demokracji, Warszawa 2004, s. 161.

${ }^{9}$ M. Grabowska, T. Szawiel, Budowanie demokracji. Podziały społeczne, partie polityczne i społeczeństwo obywatelskie w postkomunistycznej Polsce, Warszawa 2003, s. 82-83.

${ }^{10}$ M. Musiał-Karg, Referendum w państwach europejskich. Teoria, praktyka, perspektywy, Toruń 2008, s. 356.
} 
teleinformatyczne dostarczają również środków, dzięki którym obywatele mogą być informowani i edukowani. Stanowią również nowe narzędzia, dzięki którym ludzie mogą tworzyć swoiste społeczności - bez względu na odległość, warunki geograficzne czy inne ograniczenia $^{11}$.

Dziś, wpływ ICT na procesy polityczne i relacje państwo-obywatel jest określany za pomocą takich pojęć, jak teledemokracja, demokracja cyfrowa, cyberdemokracja, e-demokracja. Jak słusznie zauważa Dorota Grodzka, niezależnie od przyjętej nazwy i zakresu definicyjnego samego pojęcia, wspólne dla tych koncepcji jest przekonanie, że dzięki nowym technologiom (które gwarantują interaktywność, szybszy tryb przekazywania informacji, możliwość komunikacji zwrotnej) możliwe jest oddziaływanie na mechanizmy demokratyczne ${ }^{12}$.

Według Lewisa A. Friedlanda koncept elektronicznej demokracji oznacza radykalnie nowa formę praktyki demokratycznej zmodyfikowana przez nowe technologie informacyjne ${ }^{13}$. Termin e-demokracja po raz pierwszy pojawił się w roku 1994 i związany był z działaniami on-line prowadzonymi przez mieszkańców stanu Minnesota w Stanach Zjednoczonych. Pamiętać jednak należy, iż podobne działania właściwie od przełomu lat 60-tych i 70-tych XX wieku funkcjonowały pod wspólną nazwą teledemokracja. Jednym z najbardziej popularnych podejść do demokracji elektronicznej jest to formułowane przez Martina Hagena, według którego elektroniczna demokracja to każdy demokratyczny system polityczny, w którym używa się komputerów i sieci komputerowych do realizacji podstawowych funkcji procesu ${ }^{14}$.

E-demokrację definiuje się również jako zastosowanie technologii informacyjnych i komunikacyjnych $\mathrm{w}$ celu zwiększenia zaangażowania obywateli w procesach demokratycznych, zarówno $w$ ujęciu ilościowym, jak $i$ w formie realnego wplywu wywieranego przez jednostki na funkcjonowanie instytucji publicznych ${ }^{15}$. Działania zaliczane do elektronicznej formy demokratycznych rządów mogą być dwojakiego rodzaju: odgórne (top-down) - wymienić tu należy inicjatywy podjęte np. przez rząd czy władze lokalne, oraz oddolne (bottom-up), do których zalicza się inicjatywy podjęte np. przez obywateli czy organizacje społeczne. Niezależnie od tego, kto podejmuje inicjatywę, działania mogą mieć charakter procesów jednokierunkowych (rozpowszechnianie informacji) lub dwukierunkowych (konsultacje dotyczące projektów ustaw) ${ }^{16}$ lub też wielokierunkowych (komunikowanie poprzez bloga, gdzie internauci mogą komentować posty, poprzez czat, fora czy maile rozsyłane do wielu adresatów) ${ }^{17}$.

Elektroniczne głosowanie jest jednym z istotnych instrumentów demokracji elektronicznej, za pomocą którego urzeczywistnia się zasadę suwerenności narodu. Taka nowa formuła głosowania coraz częściej jest przedmiotem zainteresowania instytucji publicznych i prywatnych w wielu państwach Europy i świata (np. w Szwajcarii, Wielkiej Brytanii, Holandii, Szwecji, Estonii, USA). Wielu badaczy wysuwa różnorodne propozycje zastosowania roz-

${ }^{11}$ I. Horrocks, L. Pratchett, Democracy and New Technology..., op. cit.

${ }^{12}$ D. Grodzka, E-demokracja, „Infos. Zagadnienia społeczno-gospodarcze”, Biuro Analiz Sejmowych nr 14(61), 16 lipca 2009, s. 1, za: T. Białobłocki, J. Moroz, M. Nowina-Konopka, Społeczeństwo informacyjne: istota, rozwój, wyzwania, Warszawa 2006.

${ }^{13}$ L. A. Friedland, Electronic Democracy and the New Citizenship, „Media, Culture \& Society” 1996, vol. 18, nr 2, s. 185 .

${ }^{14}$ M. Hagen, A Typology of Electronic Democracy, 1997, http://www.uni-giessen.de/fb03/vinci/labore/netz/ hag_en.htm, 3.06.2010.

${ }^{15}$ D. Grodzka, E-demokracja..., op. cit., s. 1.

${ }^{16}$ Ibidem, s. 2.

${ }^{17}$ M. Musiał-Karg, Technologie informacyjne i komunikacyjne a demokracja. Wykorzystanie Internetu w polityce na przykładzie e-voting, w: W poszukiwaniu modelu demokratycznego, red. S. Zyborowicz, Toruń 2009, s. 251. 
wiązań opartych na ICT w celu zwiększenia świadomości, a przez to i wiedzy obywateli na temat systemu politycznego i zjawisk, które mają miejsce w danym kraju.

Mimo wielu trudności, jakie niesie ze sobą wykorzystanie nowych technologii, głosowania elektroniczne mogą być efektywnym narzędziem umożliwiającym szersze uczestniczenie $\mathrm{w}$ procedurach decyzyjnych.

Termin e-głosowanie jest powszechnie kojarzony z głosowaniem internetowym lub też stosowane zamiennie z tym pojęciem. Tymczasem głosowanie elektroniczne jest terminem pojęciowo szerszym niż głosowanie internetowe. E-voting dotyczy elektronicznych form wyborów, referendów i innych inicjatyw ${ }^{18}$. Głosowanie elektroniczne (e-głosowanie, e-voting) należy rozumieć jako głosowanie za pomoca środków elektronicznych [...] wyróżnić można głosowanie komputerowe, $w$ tym z kolei głosowanie on-line $i$ wreszcie głosowanie internetowe, w którym do oddania głosu stuży urzadzenie komputerowe dołaczone do Internetu ${ }^{19}$.

$\mathrm{W}$ procesie wyborczym technologie teleinformatyczne wykorzystywane są na kilka sposobów ${ }^{20}$. Pierwszym z nich jest proces zbierania, opracowania i wizualizacji wyników przesyłanych z komisji wyborczych. Wówczas głosy oddawane są w sposób tradycyjny - za pomocą kart do głosowania. Taki system obowiązuje np. w Polsce, gdzie obwodowe komisje wyborcze zanim prześlą oficjalne protokoły wyborcze do komisji wyborczych wyższego szczebla, przekazują dane do systemu teleinformatycznego, który prowadzony jest przez Państwową Komisję Wyborczą.

Drugi sposób wykorzystania ICT w procesie głosowania stosowany jest w procesie przyjmowania i zliczania głosów. Głosy są oddawane przez wyborców osobiście w lokalach wyborczych na specjalnie do tego przygotowanych komputerach wyborczych (tzw. maszyny do głosowania - voting machines).

Trzeci sposób zastosowania technologii informacyjnych i komunikacyjnych to zdalne głosowanie - np. przez Internet lub w drodze sms-a wysłanego z telefonu komórkowego. W zdalnym głosowaniu przez Internet głosy oddawane są z dowolnej lokalizacji za pomocą Internetu, a ich przyjmowaniem i zliczaniem zajmuje się centralny komputerowy system wyborczy. W drugim przypadku - w głosowaniu przez telefon komórkowy - użytkownik wysyła wiadomość tekstową zawierającą identyfikator użytkownika, kod odpowiedni do rodzaju wyborów, w których wyborca chce zagłosować oraz kod wskazujący konkretną odpowiedź. Sms przekazywany jest następnie pod odpowiedni numer, a po chwili użytkownik powinien otrzymać odpowiedź wraz z potwierdzeniem oddania głosu. Wysyła wówczas kolejną wiadomość wraz z numerem PIN i datą urodzenia. Następnie użytkownik otrzymuje wiadomość z potwierdzeniem oddania głosu.

Reasumując, wykorzystanie narzędzi teleinformatycznych w procedurze przyjmowania czy liczenia głosów i w zdalnym głosowaniu internetowym określane jest mianem elektronicznego głosowania. W literaturze specjalistycznej mowa jest zwykle o dwu formach

\footnotetext{
${ }^{18}$ I. Kotsiopoulos, Bringing Together and Accelerating eGovernment Research in the EU. eDemocracy Report. Prepared for ICT for Government and Public Services Unit. DG Information Society and Media, European Commission, Brussels, s. A-9.

${ }^{19}$ A. Kaczmarczyk, R. Czajkowski, E-Gtosowanie - niezbędny element elektronicznej platformy do obstugi procedur demokracji w spoleczeństwie informacyjnym, w: Tworzenie mechanizmów i struktur rozwoju elektronicznej gospodarki w Polsce. Warszawa, 12 czerwca 2001 r. Materiały pokonferencyjne, Instytut Logistyki i Magazynowania, Poznań 2001.

${ }^{20}$ Stanowisko Stowarzyszenia Internet Society Poland w sprawie glosowania elektronicznego w wyborach powszechnych przyjęte przez Zarząd Stowarzyszenia $w$ dniu 10 stycznia 2007 roku (uchwała Zarządu ISOC Polska nr 2/2007), 11.01.2007, Internet Society Poland, http:/www.isoc.org.pl/200701/wybory, 26.06.2010.
} 
głosowania przeprowadzanego w oparciu o ICT - wyróżnia się je w oparciu o dwie nazwy: z przedrostkiem „e-" - e-głosowanie oraz z przedrostkiem ,i-" - i-głosowanie. E-głosowanie w porównaniu z $i$-głosowaniem jest pojęciem szerszym znaczeniowo. W praktyce odnosi się do wykorzystywania w procesie techniki wyborczej m.in.: telewizyjnych platform cyfrowych, telefonii, Internetu ${ }^{21}$. I-głosowanie (i-voting) - głosowanie przy pomocy Internetu - jest jedną z form głosowania elektronicznego.

Uwzględniając natomiast podział na dwa podstawowe sposoby realizowania demokracji, a tym samym zasady zwierzchnictwa narodu, czyli demokrację przedstawicielską i bezpośrednią oraz ich instytucje - czyli wybory i referenda, wymienić można dwa rodzaje głosowania elektronicznego: elektroniczne wybory (e-wybory) i elektroniczne referendum (e-referendum). Pod względem technologicznym - ten drugi rodzaj głosowania wydaje się być mniej skomplikowanym do wprowadzenia - głównie ze względu na zwykle dwie możliwe odpowiedzi w głosowaniu (,Tak” lub „Nie”).

\section{Elektroniczne (internetowe) ${ }^{22}$ wybory w Estonii}

Europejskim liderem, jeśli chodzi o wykorzystanie elektronicznego głosowania w procedurach wyborczych, jest Estonia. Obywatele tego małego pod względem terytorium (obszar kraju zajmuje $45226 \mathrm{~km}^{2}$ ) oraz liczby populacji (populacja: 1340127 osób) ${ }^{23}$ państwa od 2005 r. mają możliwość głosowania przez Internet podczas wyborów.

Na szczeblu rządowym dyskusja nad implementacją elektronicznego głosowania w Estonii rozpoczęła się w 2001 r. Rok później estoński parlament-Zgromadzenie Państwowe (Riigikogu) - stworzył podstawy prawne do przeprowadzenia głosowania przez Internet ${ }^{24}$. Latem 2003 roku Państwowa Komisja Wyborcza w Estonii zaczęła wdrażać projekt systemu e-głosowania ${ }^{25}$. Wysoka tzw. e-gotowość (e-readiness) mieszkańców Estonii, nowoczesna infrastruktura IT wprowadzana przy wsparciu programu rządowego, a także bardzo dobra współpraca sektora publicznego z prywatnym stanowiły kluczowe czynniki w procesie wdrażania i rozwoju elektronicznych usług (e-usług) w tym państwie. Szerokie zastosowanie specjalnych dowodów tożsamości nowej generacji (ID-card) było niezbędne dla wprowadzenia nowego kanału głosowania. W styczniu 2000 r. weszła w życie ustawa dotycząca nowych dowodów osobistych (Identity Documents Act), wprowadzając od 2002 r. obowiązek posiadania eID-card ${ }^{26}$.

\footnotetext{
${ }^{21}$ M. Nowina Konopka, Elektroniczna urna, http://www.rpo.gov.pl/pliki/12066058070.pdf, 27.06.2010.

${ }^{22} \mathrm{~W}$ przypadku głosowania elektronicznego w Estonii - mimo iż stosowane jest tam głosowanie internetowe - wykorzystywane będą zamiennie dwie nazwy: e-głosowanie (e-voting) oraz i-głosowanie (i-voting). Ma to związek przede wszystkim z tym, iż na stronach Estońskiej Państwowej Komisji Wyborczej najczęściej podawana jest nazwa z przedrostkiem ,e-".

${ }^{23}$ Dane na dzień 1 stycznia 2010 r., Statistics Estonia 2010, http://www.stat.ee/main-indicators, 10.11.2010.

${ }^{24}$ Digital Signature Act 2002 - ustawa pozwala obywatelom używać przyjętych podpisów elektronicznych w celu potwierdzania tożsamości w transakcjach on-line, a także w głosowaniu; N. Goodman, J. H. Pammett, J. DeBardeleben, J. Freeland, A Comparative Assessment of Electronic Voting, Strategic Knowledge Cluster Canada-Europe Transatlantic Dialogue, Carlton University, February 2010, s. 33, http:/www.carleton.ca/europecluster/events/ 2010-01-26-InternetVotingMaterials/AComparativeAssessmentofInternetVotingFINALFeb19-a.pdf, 15.10.2010.

${ }^{25}$ E. Maaten, Towards remote e-voting: Estonian case, Elections Departament. Chancellery of the Riigikogu (Parliament), Tallin 2004, Materiały konferencyjne $\mathrm{z}$ The International Workshop on Electronic Voting in Europe, Bregenz/Austria, 7-9.07.2004, s. 83, http://www.e-voting.at/index.php?id=4\&artikelID=62, 15.10.2010.

${ }^{26}$ W 2005 r. posiadacze nowych eID cards stanowili około 900 tys.; Estonian National Electoral Committee, http://www.vvk.ee/index.php?id=11178\&tpl=1062, 20.08.2009.
} 
Takie dowody osobiste, wydane przez rząd Estonii od 2002 r., mają dwojakie funkcje: oprócz tego, że są dokumentami identyfikacyjnymi, służą również do potwierdzania tożsamości elektronicznej. Warto w tym miejscu nadmienić, iż biorąc pod uwagę kryterium miejsc oddawania głosów można wyróżnić dwie formy $i$-voting:

- Remote Internet Voting (RIV, zdalne głosowanie internetowe), czyli głosowanie, w którym głosy oddawane są $\mathrm{w}$ dowolnym miejscu $\mathrm{z}$ wykorzystaniem połączenia internetowego, a następnie transferowane są przez Internet do urzędników wyborczych;

- Internet Voting at the Polling Place (IV@PP, głosowanie internetowe w lokalu wyborczym), czyli głosowanie, gdzie głosy oddawane są przez wyborców w lokalach wyborczych (często za pomocą tzw. maszyn lub kiosków do głosowania), a następnie przekazywane Internetem do urzędników wyborczych ${ }^{27}$.

W Estonii - jak do tej pory - wprowadzono pierwszą z wymienionych powyżej form głosowania przez Internet - Remote Internet Voting. Aby oddać głos przez Internet estoński wyborca potrzebuje: dowodu osobistego nowej generacji, czyli wspomnianej już elektronicznej karty identyfikacyjnej (eID-card) z ważnymi certyfikatami (odnawianymi na stronie www), kodów PIN (wydawanych razem z kartami eID) oraz komputera wyposażonego w czytnik kart eID (wraz z odpowiednim oprogramowaniem - instalacja installer.id.ee/), połączenia $z$ Internetem oraz systemu operacyjnego Windows, MacOS lub Linux ${ }^{28}$.

Jedną z najważniejszych kwestii ustalonych przy wdrażaniu systemu i-głosowania był fakt, iż głosowanie elektroniczne musi być tak podobne do głosowania tradycyjnego jak to tylko możliwe. Oprócz tego warunkiem wprowadzenia w życie $i$-voting była zgodność głosowania z prawem i zasadami wyborów, a także to by i-głosowanie było co najmniej w takim stopniu bezpieczne jak jest oddawanie głosów w sposób tradycyjny. Stąd głosowanie przez Internet musi być równe i tajne, wyłącznie osoby uprawnione do głosowania mogą uczestniczyć w i-głosowaniu, przy czym każdy wyborca ma do dyspozycji wyłącznie jeden i-głos. Warto nadmienić, iż zgodnie $\mathrm{z}$ ustaleniami wyborca nie może być w stanie dowieść w jaki sposób głosował - np. na którego z kandydatów. Ponadto, sam proces zbierania głosów winien być bezpieczny i wiarygodny ${ }^{29}$.

Zgodnie z estońskim prawem wyborczym ${ }^{30}$ e-głosowanie odbywa się od 10-go do 4-go dnia przed dniem wyborów i spełnione winny być wówczas następujące wymagania (warunki):

1) w trakcie wcześniejszego głosowania wyborcy mogą oddać głos elektroniczny na stronie internetowej Państwowej Komisji Wyborczej. Wyborca głosuje w swoim imieniu; 2) wyborca dokonuje uwierzytelnienia ${ }^{31}$ na podstawie certyfikatu wydanego na podstawie Ustawy o Dokumentach Identyfikacji Personalnej (Personal Identity Documents Act);

${ }^{27}$ R. K. Gibson, Internet Voting and the European Parliament elections: problems and prospects, w: The European Union and E-Voting. Addressing the European Parliament's Internet Voting Challenge, ed. A. H. Trechsel, F. Mendes, Routledge 2005, s. 34.

${ }^{28}$ Estonian National Electoral Committee, http://www.vvk.ee/index.php?id=11178\&tpl=1062, 10.10.2010.

${ }^{29}$ E-Voting System. General Overview, Estonian National Electoral Committee, Tallin 2005-2010, s. 7.

${ }^{30}$ Riigikogu Election Act, Local Government Council Election Act, Referendum Act and European Parliament Election Act - wszystkie cztery ustawy zawierają podobne warunki e-głosowania.

${ }^{31}$ Uwierzytelnianie (ang. authentication) jest procesem stwierdzenia autentyczności, czyli wiarygodności tożsamości użytkownika. Polega na zweryfikowaniu zadeklarowanej tożsamości osoby. Uwierzytelnienie odbywa się na podstawie trzech informacji: tego, co użytkownik wie, tego, co użytkownik ma i tego, kim użytkownik jest. Szerzej: Z. Suski, Materiały pomocnicze do wykładu z przedmiotu „Bezpieczeństwo systemów informatycznych”; tytuł wykładu: „Uwierzytelnianie”, http://pjwstk.wafel.com/bsi/BSI-05-uwierzytelnianie.pdf, 12.09.2010. Proces uwierzytelnienia ma miejsce po identyfikacji, czyli zadeklarowaniu swojej tożsamości przez użytkownika (np. przez podanie loginu). Zadeklarowana, ale jeszcze niezweryfikowana, tożsamość jest potwierdzana w procesie uwierzytel- 
3) po identyfikacji wyborcy, na stronie internetowej wyświetlana jest skonsolidowana lista kandydatów wybieranych w okręgu wyborczym, na terenie którego zamieszkuje wyborca;

4) wyborca wybiera (wskazuje) nazwisko kandydata, na którego zamierza zagłosować w swoim okręgu wyborczym i potwierdza głos podpisem elektronicznym;

5) na stronie internetowej wyświetla się komentarz o tym, że oddany głos został uwzględniony w głosowaniu;

6) wyborca może zmienić oddany wcześniej głos elektroniczny:

a) przez ponowne elektroniczne głosowanie w okresie od 10-go do 4-go dnia przed dniem wyborów tradycyjnych,

b) poprzez głosowanie na papierowej karcie do głosowania w okresie od 6-go do 4-go dnia przed dniem wyborów tradycyjnych ${ }^{32}$.

Dodatkowo, należy wspomnieć o zasadach, które obowiązują przy e-voting w Estonii. Pierwszą z nich jest reguła, że do uwierzytelnienia wyborców służą wyłącznie elektroniczne dowody tożsamości (od 2011 r. będą również możliwe rozwiązania oparte na mobilnym uwierzytelnieniu - Mobile-ID solution). Karta-ID (jak i Mobile-ID) jest bowiem jedynym niezależnym środkiem komunikacji elektronicznej, który umożliwia uwierzytelnienie wyborców na maksymalnym poziomie bezpieczeństwa czy złożenie podpisu elektronicznego. Godzi się w tym miejscu ponadto zauważyć, iż taki nowoczesny dokument posiada już większość uprawnionych do głosowania. Ten ostatni aspekt ma kluczowe znaczenie - szczególnie jeśli chodzi o przyjęty w Estonii system e-głosowania.

Drugą regułą, która obowiązuje w Estonii, jest możliwość ponownego elektronicznego głosowania - wyborca może oddać głos po raz kolejny, a poprzednio oddany głos zostaje wówczas anulowany. Choć zwykle wielokrotne głosowanie uznawane jest za przestępstwo (Kodeks karny, § 165), w tym przypadku jest to argument przeciwko zjawisku kupowania głosów - wyborca, na którego uprzednio bezprawnie wywarto wpływ, może oddać głos na nowo, gdy już nikt nie próbuje na niego wpłynąć. Elektroniczne ,ponowne głosowanie” nie może więc być uznawane za „wielokrotne”, ponieważ system uwzględni wyłącznie jeden głos (oddany jako ostatni).

Kolejną ważną zasadą jest traktowanie głosowania tradycyjnego jako priorytetowego. Wyborca, który zagłosował uprzednio elektronicznie, jeśli w dniu głosowania tradycyjnego pójdzie do lokalu wyborczego i tam odda głos - jego elektroniczny głos skreśla się. Uzasadnienie tej zasady jest podobne do poprzedniego. Jeśli zajdzie podejrzenie lub naruszenie elektronicznego głosowania, a wszystkie lub niektóre e-głosy uznane zostaną za nieważne, wówczas możliwe jest głosowanie w sposób tradycyjny ${ }^{33}$.

$\mathrm{Z}$ technicznego punktu widzenia wymagane jest, by system elektronicznego (internetowego) głosowania w Estonii był tak prosty jak to tylko możliwe, a także tak transparentny, by specjaliści od tego typu przedsięwzięć mogli go sprawdzać co do funkcjonowania. Zgodnie z przyjętymi w Estonii założeniami, system e-głosowania musi być także przeznaczony do

nienia (np. przez podanie hasła). Uwierzytelnienie to jest bardzo istotne z punktu widzenia bezpieczeństwa sieci komputerowych - jest swego rodzaju dodatkowym poziomem kontroli dostępu do zasobów sieciowych. Szerzej: Z. Świerczyński, Wybrane metody uwierzytelnienia użytkownika sieci komputerowej, Instytut Teleinformatyki i Automatyki WAT, Warszawa, s. 30, http://www.ita.wat.edu.pl/ zswier/SBS/Uwierzytelnianie.pdf, 19.11.2010.

${ }^{32}$ E-Voting System. General Overview..., op. cit., s. 7.

${ }^{33}$ Ibidem, s. 7-8. 
wielokrotnego stosowania - w ten sposób by przy kolejnych wyborach nie istniała potrzeba opracowywania nowego systemu opartego na metodach elektronicznych ${ }^{34}$.

Projekt e-głosowania już od roku 2001 uznano za ważny element rządowej strategii, polegającej na wykorzystaniu technologii cyfrowych w celu uczynienia sektora publicznego bardziej wydajnym, skutecznym i przyjaznym dla klientów. Ówczesna koalicja rządowa uzgodniła, iż e-głosowanie powinno po raz pierwszy być dostępne dla wyborców w momencie wyborów do władz lokalnych w roku $2005^{35}$. Jako najważniejsze przyczyny wprowadzenia dodatkowego sposobu głosowania w Estonii wymienić należy: udostępnienie dodatkowego i wygodnego kanału oddawania głosu, a przez to unowocześnienie głosowania, a także umożliwienie bardziej wydajnego wykorzystania istniejącej infrastruktury (cyfrowe platformy oraz elektroniczne eID-karty).

\section{E-wybory w praktyce}

W Estonii w okresie od 2005 do 2009 r. głosowanie internetowe o wiążącym charakterze przeprowadzono czterokrotnie. Po raz pierwszy wyborcy mieli możliwość oddania głosu przez Internet w 2005 r. przy okazji wyborów samorządowych. Dwa lata później wyborcy głosowali internetowo w wyborach parlamentarnych. W roku 2009 Estończycy mogli głosować za pomocą Internetu dwukrotnie - najpierw w czerwcu w drugich w tym kraju wyborach do Parlamentu Europejskiego oraz w październiku w wyborach do władz do lokalnych.

Zanim dokonana zostanie analiza danych dotyczących poziomu i-głosowania w poszczególnych wyborach, warto zwrócić uwagę na fakt, iż Estonia jest jednym z najintensywniej rozwijających się państw europejskich jeśli chodzi o wykorzystanie Internetu oraz innych narzędzi ICT - zarówno w sektorze prywatnym, jak i publicznym. Należy ponadto zaznaczyć, iż Estonia jest jedynym państwem w Europie, gdzie dostęp do Internetu jest prawnie ustanowiony prawem socjalnym. Już w roku 2000 Riigikogu przyjął propozycję, by każdy Estończyk miał zagwarantowany dostęp do Internetu tak, jak inne prawa konstytucyjne ${ }^{36}$.

\footnotetext{
${ }^{34}$ Jeśli chodzi o sam akt wyborczy, to należy pamiętać, iż zaangażowane w niego są zawsze dwie strony: wyborca oraz odbiorca głosu. W głosowaniu elektronicznym natomiast tymi stronami są komputer wyborcy oraz serwery prowadzone przez i pod nadzorem Państwowej Komisji Wyborczej (the National Electoral Committee - NEC). Najsłabszym ogniwem procedury e-głosowania jest zapewne będący własnością wyborcy - komputer, nad którym nie ma kontroli. Mimo, iż serwery Państwowej Komisji Wyborczej mogą być kontrolowane, to pojawiające się błędy czy ataki mogą wpłynąć na dużą liczbę głosów jednocześnie. System e-głosowania traktuje te kwestie bardzo poważnie, E-Voting System. General Overview..., op. cit., s. 8.

${ }^{35}$ E. Maaten, Towards remote e-voting..., op. cit., 83.

${ }^{36}$ Obywatele mogą zatem korzystać z internetu za pośrednictwem jednego z 729 Publicznych Punktów Dostępu do Internetu (Public Internet Access Points - PIAP). Jak podaje Ministerstwo Spraw Gospodarczych i Komunikacji - na 100 tys. osób przypada 51 tego typu punktów, które oznakowane są specjalnymi znakami drogowymi - z symbolem „@”. Większość PIAP-ów umiejscowionych jest w bibliotekach lub innych budynkach komunalnych w całym kraju, a korzystanie z nich nie wiąże się z uiszczaniem jakichkolwiek opłat. Estonia dysponuje obecnie ponad 600 strefami (place miejskie, stacje paliw, hotele, puby itp.), które umożliwiają korzystanie z bezprzewodowego Internetu. Wszystkie szkoły w Estonii mają podłączenie do Internetu, co jest rezultatem wdrożenia w latach 1997-1999 państwowego programu „Tiger Leap” (,Skok Tygrysa”). Warto nadmienić, iż nawet geograficznie odizolowana wyspa Ruhnu zamieszkiwana przez około 40 osób w swojej szkole, gdzie uczy się troje uczniów ma infrastrukturę internetową. Jednym z celów programu rządowego jest zagwarantowanie jednego komputera na dwadzieścioro uczniów w każdej szkole. Case Study 2: E-Stonia, The Judith and John Bedrosian Center on Governance and the Public Enterprise, University of Southern Kalifornia, http://www.usc.edu/schools/sppd/bedrosian/private/docs/Case_Study_Estonia.pdf, 10.10.2010.
} 
Będąc jednym z wiodących światowych inwestorów w obszarze ICT, Estonia zdołała zbudować niezwykle silną infrastrukturę technologiczną: już w 2009 r. aż 63\% gospodarstw domowych w tym małym europejskim państwie dysponowało podłączeniem do Internetu. Od momentu wprowadzenia po raz pierwszy głosowania internetowego w roku 2005 - liczba gospodarstw podłączonych do Internetu się niemal podwoiła. Obecnie więcej niż 70\% Estończyków w przedziale wiekowym od 16 do 74 roku korzysta z Internetu ${ }^{37}$.

Tabela 1

Podlączenie do Internetu i użytkownicy Internetu w Estonii (w \%)

\begin{tabular}{|l|c|c|c||}
\hline & $\mathbf{2 0 0 5}$ & $\mathbf{2 0 0 7}$ & $\mathbf{2 0 0 9}$ \\
\hline Gospodarstwa domowe z podłączeniem do Internetu & 38,5 & 52,9 & 63,0 \\
\hline Użytkownicy Internetu (przedział wiekowy: 16-74 lat) & 59,2 & 63,6 & 71,2 \\
\hline
\end{tabular}

Źródło: Statistics Estonia, http://www.stat.ee/, 12.10.2010; Case Study 2: E-Stonia, The Judith and John Bedrosian Center on Governance and the Public Enterprise, University of Southern Kalifornia, http://www.usc.edu/schools/ sppd/bedrosian/private/docs/Case_Study_Estonia.pdf, 10.10.2010.

Wybory do władz lokalnych w roku 2005 odbyły się w Estonii w październiku. Głosowanie internetowe możliwe było w dniach 10-12 października 2005 r. Aby wziąć udział w głosowaniu internetowym, potrzeba było mieć dostęp do komputera z podłączeniem do Internetu, kartę ID z ważnym certyfikatem, kody PIN i czytnik kart. W tabeli 2 zaprezentowano szczegółowe dane na temat głosowania.

Tabela 2

Wybory do władz lokalnych w Estonii w październiku 2005 r. i 2009 r. - zestawienie wyników

\begin{tabular}{|l|c|c||}
\hline & $\begin{array}{c}\text { Wybory do władz } \\
\text { lokalnych 2005 r. }\end{array}$ & $\begin{array}{c}\text { Wybory do władz } \\
\text { lokalnych 2009 r. }\end{array}$ \\
\hline Liczba osób uprawnionych do głosowania & $\mathbf{1 0 5 9 2 9 2}$ & $\mathbf{1 0 9 4} \mathbf{3 1 7}$ \\
\hline Liczba oddanych głosów (lącznie z i-głosami) & $\mathbf{5 0 2} \mathbf{5 0 4}$ & $\mathbf{6 6 2} \mathbf{8 1 6}$ \\
\hline Frekwencja wyborcza & $\mathbf{4 7 , 4 3 \%}$ & $\mathbf{6 0 , 6 \%}$ \\
\hline Liczba i-głosów & $\mathbf{9 6 8 1}$ & $\mathbf{1 0 6} \mathbf{7 8 6}$ \\
\hline Liczba i-wyborców & 9317 & 104413 \\
\hline Liczba i-głosów uwzględnionych w finalnych wynikach & 9287 & 104313 \\
\hline Liczba i-głosów powtórzonych & 364 & 2373 \\
\hline Liczba i-głosów anulowanych (wyborca głosował tradycyjnie) & 30 & 100 \\
\hline $\begin{array}{l}\text { Udział uwzględnionych i-głosów w stosunku do wszystkich } \\
\text { oddanych głosów }\end{array}$ & $1,85 \%$ & $15,74 \%$ \\
\hline I-frekwencja & $\mathbf{0 , 9 1 \%}$ & $\mathbf{9 , 7 6 \%}$ \\
\hline
\end{tabular}

Źródło: Estonian National Electoral Committee, http://www.vvk.ee/index.php?id=11178\&tpl=1062, 18.10.2010.

Jak widać, w wyborach samorządowych 9317 wyborców skorzystało ze sposobności, by oddać głos internetowo - głosując w ten sposób łącznie 9681 razy. Przy obliczaniu finalnego wyniku wyborów pod uwagę wzięto 9287 i-głosów, czego przyczyną był fakt, iż 364 głosy

${ }^{37}$ Two thirds of households of Estonia have access to the Internet at home, 18.09.2009, Statistics Estonia, http://www.stat.ee/index.php?id=31246\&highlight=internet,connection, 15.10.2010. 
były oddane po raz drugi przez tego samego wyborcę, a dodatkowo 30 osób, które oddało głos internetowo, zdecydowało się ostatecznie głosować w lokalu wyborczym. W pierwszym przypadku (gdy ktoś głosuje internetowo po raz kolejny) - zgodnie z obowiązującymi zasadami - ostatni głos jest brany pod uwagę, natomiast gdy ktoś po uprzednio oddanym i-głosie, głosuje jeszcze w sposób tradycyjny - na drukowanej karcie wyborczej - ten ostatni głos jest uwzględniany, a i-głos jest anulowany.

Niecałe $2 \%$ spośród wszystkich, którzy oddali głos w wyborach samorządowych, zagłosowało za pośrednictwem Internetu. Biorąc pod uwagę, że głosowanie elektroniczne przeprowadzano wówczas po raz pierwszy, czytniki do kart ID nie były jeszcze tak popularne, na początku roku 2005 wygasły certyfikaty w dużej części elektronicznych dowodów i istniała potrzeba ich odnowienia - wynik i-wyborów - według autorów raportu prezentowanego na stronach Estońskiej Państwowej Komisji Wyborczej - należało uznać za względnie dobry rezultat ${ }^{38}$.

Kolejne wybory do władz lokalnych w Estonii odbyły się cztery lata później i również dopuszczały możliwość głosowania za pośrednictwem Internetu. I-głosowanie przeprowadzano od godziny 9:00 rano 8 października do godziny 20:00 dnia 14 października 2009 r. W kontekście wyborów w Estonii warto wspomnieć, iż wyborcy mają możliwość wcześniejszego tradycyjnego głosowania przy urnach wyborczych, co akurat w tym przypadku możliwe było w dniach od 12 do 14 października w godzinach od 12:00 do 20:00. Z takiej możliwości mogli skorzystać zarówno wyborcy, którzy przebywali, jak i nie przebywali na terenie swego okręgu wyborczego. 18 października 2009 r. możliwe było wyłącznie głosowanie w lokalu wyborczym w odpowiednim dla zamieszkania wyborcy lokalu wyborczym ${ }^{39}$.

W wyborach do władz lokalnych z października 2009 r. na prawie 1 mln 100 tys. uprawnionych do głosowania uczestniczyło około 663 tys. wyborców, z których około 104 tys. zdecydowało się zagłosować na swoich kandydatów za pośrednictwem Internetu. Łącznie (wraz z 2373 i-głosami powtórzonymi) 104413 uprawnionych do głosowania oddało 106786 głosów elektronicznych. Co bardzo ciekawe, 100 wyborców po tym, jak zagłosowało elektronicznie, uczestniczyło ostatecznie w tradycyjnym głosowaniu w lokalu wyborczym.

W porównaniu z poprzednimi wyborami do estońskich władz lokalnych widać praktycznie ośmiokrotny wzrost liczby oddawanych głosów internetowych w stosunku do wszystkich głosów oddanych w wyborach. W 2005 r. udział i-głosów w stosunku do wszystkich oddanych głosów wyniósł $1,85 \%$, natomiast cztery lata później - w czwartych wyborach, w których istniała możliwość i-głosowania - udział i-głosów w stosunku do wszystkich oddanych głosów wyniósł 15,74\%. Na podstawie choćby tego jednego wskaźnika widać duży postęp w rozwoju e-wyborów w Estonii, czego dowodem jest fakt większej liczby wyborców, którzy decydują się uczestniczyć w procesach wyborczych z wykorzystaniem Internetu. Wynik i-wyborów w roku 2009 uznać należy za bardzo dobry rezultat ${ }^{40}$.

Kolejnym głosowaniem ogólnopaństwowym, w którym Estończycy mieli możliwość oddawania głosu za pośrednictwem Internetu były wybory do parlamentu w 2007 r. Wybory przy urnach wyborczych obyły się 4 marca 2007 r., a głosowanie elektroniczne przeprowa-

38 Ü. Madise, P. Vinkel, E. Maaten, Internet Voting at the Elections of Local Government Councils on October 2005. Report, Estonian National Electoral Committee, http://www.vvk.ee/public/dok/report2006.pdf, s. 28.

${ }^{39} \mathrm{~W}$ tym przypadku adres odpowiedniego lokalu wyborczego podany jest na karcie do głosowania wysłanej na adres zamieszkania konkretnego wyborcy lub na jego elektronicznej karcie wyborczej.

${ }^{40}$ Ü. Madise, P. Vinkel, E. Maaten, Internet Voting at the Elections of Local Government Councils on October 2005. Report, Estonian National Electoral Committee, http://www.vvk.ee/public/dok/report2006.pdf, s. 28. 
dzone było w ciagu trzech dni od 26 lutego od godziny 9:00 rano do 28 lutego do godziny 20:00. Wykorzystanie głosowania internetowego w estońskich państwowych wyborach parlamentarnych było głosowaniem rzeczywiście symbolicznym i pierwszym tego typu w skali świata. Mimo tego, że Internet był stosowany już w 2005 r. w wyborach do władz lokalnych, w różnego rodzaju głosowaniach o charakterze konsultacyjnym, w głosowaniach prywatnych czy w referendach, parlamentarne wybory w Estonii były pierwszymi na świecie, gdzie elektorat całego kraju, by wybrać skład parlamentu miał możliwość oddania głosu w sposób elektroniczny ${ }^{41}$.

Tabela 3

Wybory parlamentarne w Estonii w marcu 2007 r. - zestawienie wyników

\begin{tabular}{|c|c|}
\hline Liczba osób uprawnionych do głosowania & 897243 \\
\hline Liczba oddanych głosów (lącznie z i-głosami) & 555563 \\
\hline Frekwencja wyborcza & $61,91 \%$ \\
\hline I-głosy (wraz z 789 e-głosami powtórzonymi) & 31064 \\
\hline Liczba i-wyborców & 30275 \\
\hline Liczba i-głosów uwzględnionych w finalnych wynikach & 30243 \\
\hline Liczba i-głosów anulowanych (wyborca głosował tradycyjnie) & 32 \\
\hline Udział uwzględnionych i-głosów w stosunku do wszystkich oddanych głosów & $5,44 \%$ \\
\hline I-frekwencja & $3,46 \%$ \\
\hline
\end{tabular}

Źródło: Estonian National Electoral Committee, http://www.vvk.ee/index.php?id=11178\&tpl=1062, 18.10.2010.

Jak widać w tabeli 3 ponad 30 tys. wyborców na prawie 900 tys. uprawnionych skorzystało z tej możliwości. Estońskie i-wybory z 2007 r. były drugimi z kolei w tym kraju (po wyborach do władz lokalnych z 2005 r.), gdzie wyborcy mogli zdecydować się na głosowanie za pośrednictwem Internetu ${ }^{42}$. Analiza danych wskazuje, iż w porównaniu do roku 2005 mimo względnie niewielkiego udziału i-wyborców w stosunku do wszystkich osób uprawnionych do głosowania, poziom zainteresowania nową metodą uczestnictwa w procedurach wyborczych wzrósł. Udział uwzględnionych i-głosów w stosunku do wszystkich oddanych głosów w 2005 kształtował się na poziomie 1,85\%, natomiast w roku 2007 osiagnął już 5,44\%.

Dwa lata po krajowych wyborach parlamentarnych przeprowadzono w Estonii-podobnie jak w dwudziestu sześciu pozostałych państwach Unii Europejskiej - wybory do Parlamentu Europejskiego. Wybory z czerwca 2009 r. były drugimi z kolei eurowyborami w Estonii (pierwsze odbyły się 13 czerwca 2004 r., frekwencja wyborcza wyniosła wówczas 26,89\% ${ }^{43}$ )

${ }^{41}$ A. H. Trechsel, Internet voting in the March 2007 Parliamentary Elections in Estonia. Report for the Council of Europe, European Union Democracy Observatory (EUDO), Robert Schuman Centre for Advanced Studies, European University Institute Florence, 31 July 2007, s. 7.

${ }^{42}$ Warto zaznaczyć, iż partycypacja wyborcza osiagnęła w 2007 r. prawie $62 \%$ (podczas gdy cztery lata wcześniej frekwencja wynosiła 58\%). W kontekście wyników wyborów godzi się zauważyć, iż Estońska Partia Reform (Eesti Reformierakond), Partia Centrum (Eesti Keskerakond) i Unia Pro Patria i Res Publica (Isamaa ja Res Publica Liit) uzyskały w wyborach odpowiednio 31,29 i 19 mandatów i stały się tym samym najsilniejszymi ugrupowaniami politycznymi w Riigikogu (składającym się ze 101 posłów). Koalicja rządowa została skonstruowana przez Estońską Partię Reform, Unię Pro Patria i Res Publica oraz Estońską Partię Socjaldemokratyczną (Eesti Sotsiaaldemokraatlik Erakond). 5 kwietnia 2007 na czele rządu stanął Andrus Ansip. A. H. Trechsel, Internet voting..., op. cit., s. 11.

${ }^{43}$ European Parliament Elections 2004 : results, 29.06.2004, EurActiv.com, http://www.euractiv.com/en/elections/european-parliament-elections-2004-results/article-117482, 13.11.2010. 
i trzecimi, w których elektorat - oprócz metody tradycyjnej - głosował przez Internet. Eurowybory w roku 2009 wzbudziły większe zainteresowanie wyborców, o czym świadczy wyższa o około $17 \%$ frekwencja wyborcza.

Tabela 4

Wybory do Parlamentu Europejskiego w Estonii w czerwcu 2009 r.

- zestawienie wyników

\begin{tabular}{|c|c|}
\hline Liczba osób uprawnionych do głosowania & 909628 \\
\hline Liczba oddanych głosów (lącznie z i-głosami) & 399181 \\
\hline Frekwencja wyborcza & $43,88 \%$ \\
\hline I-głosy (wraz z 910 e-głosami powtórzonymi) & 59579 \\
\hline Liczba i-wyborców & 58669 \\
\hline Liczba i-głosów uwzględnionych w finalnych wynikach & 58614 \\
\hline Liczba i-głosów anulowanych (wyborca głosował tradycyjnie) & 55 \\
\hline Udział uwzględnionych i-głosów w stosunku do wszystkich oddanych głosów & $14,68 \%$ \\
\hline I-frekwencja & $6,54 \%$ \\
\hline
\end{tabular}

Źródło: Estonian National Electoral Committee, http://www.vvk.ee/index.php?id=11178\&tpl=1062, 18.10.2010.

Ta sama tendencja obserwowalna była jeśli chodzi o tzw. i-frekwencję: od ostatnich i-wyborów w 2007 r. udział wyborców decydujących się na elektroniczne oddanie głosów wzrósł z 3,46\% do poziomu 6,54\%. Konsekwentnie zmieniła się również skala i-głosów w stosunku do wszystkich głosujących: w roku 2007 - 5,44\%, natomiast trochę nieco dwa lata później - 14,68\%.

Dane te mogą sugerować, iż głosowanie on-line w Estonii staje się coraz bardziej popularną forma uczestniczenia w procedurach wyborczych, i co ciekawe - ma to szczególne znaczenie przy wyborach do PE, które traktowane są zwykle jako wybory o mniejszej randze niż te o charakterze stricte krajowym. Podejście to związane jest z koncepcją second-order elections, która tłumaczy m.in. frekwencję obywateli w głosowaniach europejskich. Według tego podejścia wybory europejskie postrzegane są przez elektorat, partie polityczne czy media jako mniej ważne od first-order elections, czyli od wyborów krajowych, w których wyborcy mają wpływ na skład parlamentu czy rządu. Cechami charakterystycznymi wyborów „drugiego rzędu" są m.in.: niższa niż w wyborach krajowych frekwencja wyborcza ${ }^{44}$. Z punktu widzenia niniejszych rozważań, należałoby przypuszczać, że partycypacja elektoratu w drugich estońskich wyborach do PE będzie na podobnym poziomie, jak cztery lata wcześniej. Okazało się jednak, iż na 12 państw UE przyjętych w roku 2004 i później - tylko w pięciu frekwencja w eurowyborach wzrosła, a w Estonii wzrost ten był najwyższy - na poziomie około $17 \%$. Jednak z powodu braku badań elektoratu, nie można stawiać tezy, iż nowa metoda głosowania mogła mieć wpływ na wyższy niż wcześniej poziom frekwencji. Niemniej jednak należy zwrócić szczególną uwagę na fakt, iż w stosunku do poprzednich wyborów - w 2009 r. rola wyborów internetowych zwiększyła się istotnie.

\footnotetext{
44 Oprócz niższej frekwencji, w tzw. second-order elections wyborcy są bardziej skłonni do głosowania na tzw. partie protestu lub te, które są na peryferiach sceny politycznej a nie na partie, które odgrywają największą rolę w życiu politycznym, wyborcy ,wykorzystują” wybory second-order do ukarania lub nagrodzenia partii rządzących.
} 


\section{Internetowe wybory w Estonii - podsumowanie}

Badania nad wykorzystaniem i efektywnością $i$-voting w Estonii wskazują, iż nastawienie Estończyków do tej nowej formy głosowania na początku procesu wdrażania $e$-voting, jak i obecnie było i jest pozytywne, a skorzystanie z możliwości i-głosowania jest zależne głównie od zaufania względem tej nowej metody, a nie - jak wcześniej przypuszczano - od wpływów politycznych. Niezmiernie istotnym jest fakt, iż z wyborów na wybory coraz większa część estońskiego elektoratu uczestniczy w elekcjach, oddając swoje głosy on-line.

Tabela 5

I-wybory w Estonii - zestawienie wybranych danych (w \%)

\begin{tabular}{|l|r|r|r|r||}
\hline \multicolumn{1}{|c|}{ Wybory } & $\mathbf{1 0 . 2 0 0 5}$ & $\mathbf{0 3 . 2 0 0 7}$ & $\mathbf{0 6 . 2 0 0 9}$ & $\mathbf{1 0 . 2 0 0 9}$ \\
\hline Frekwencja (\%) & 47,43 & 61,91 & 43,88 & 60,60 \\
\hline i-frekwencja (\%) & 0,91 & 3,46 & 6,54 & 9,74 \\
\hline Udział i-głosów w stosunku do wszystkich oddanych głosów (\%) & 1,85 & 5,44 & 14,68 & 15,74 \\
\hline
\end{tabular}

Źródło: Opracowanie własne na podstawie danych Estonian National Electoral Committee.

Jak widać na wykresie 1 poziom frekwencji internetowej (liczba i-głosów w stosunku do liczby wszystkich uprawnionych do głosowania) oraz udział i-głosów w stosunku do wszystkich oddanych głosów systematycznie wzrasta, przy czym nie widać korelacji między frekwencją wyborczą a wskaźnikami i-głosowania. Nawet, gdy frekwencja jest niższa niż w poprzednich wyborach (jak w roku 2009 w stosunku do wyborów z 2007 r.), udział głosów internetowych systematycznie rośnie.

Wykres 1. I-wybory w Estonii - zestawienie wybranych danych w latach 2005-2009

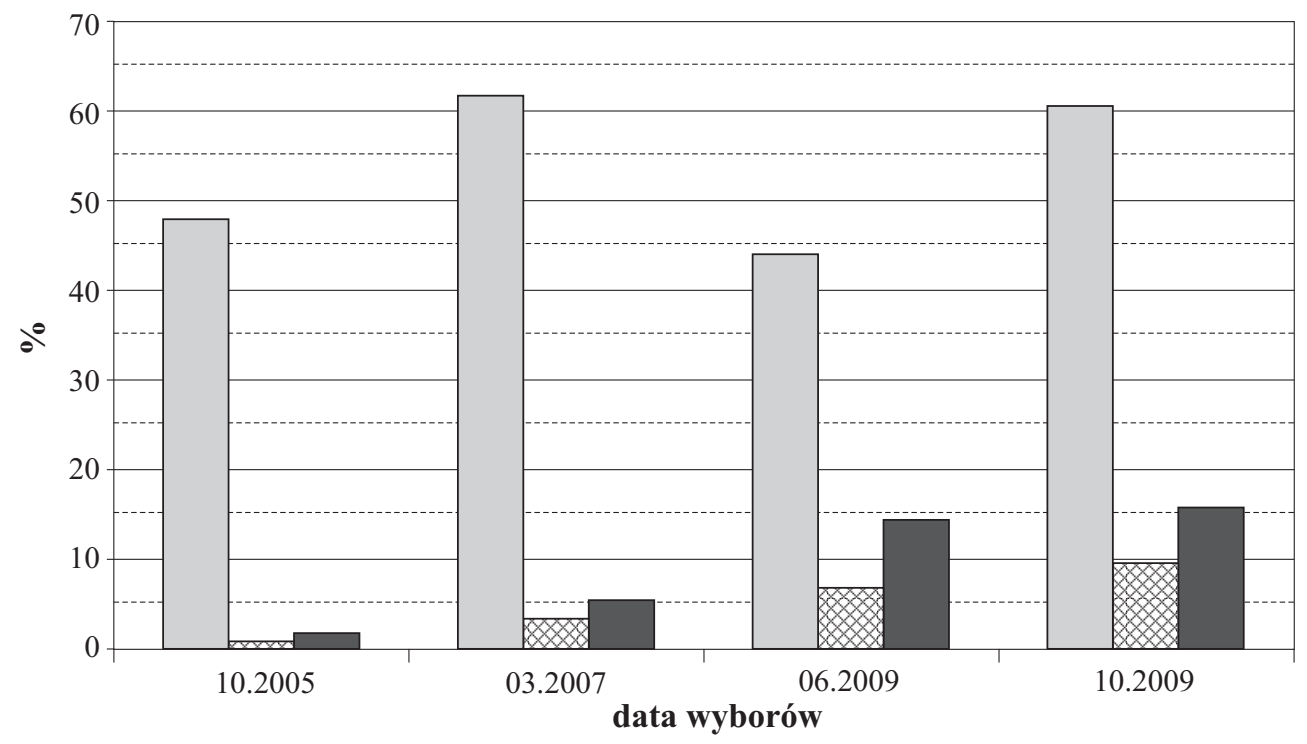

Frekwencja 园 I-frekwencja $\square$ Udział i-głosów w stosunku do wszystkich oddanych głosów

Źródło: Opracowanie własne na podstawie danych Estonian National Electoral Committee. 
Płeć i wiek stanowią dwa wskaźniki demograficzne, które budzą zainteresowanie w kontekście głosowania internetowego - szczególnie jeśli chodzi o wybór tego nowego kanału uczestnictwa w procedurach wyborczych. Można zatem postawić pytanie: czy młodsi wyborcy bardziej niż starsi są skłonni głosować przez Internet?

Rozważając zachowania wyborcze związane z wyborem metody głosowania przez pryzmat wieku osób uprawnionych, oczywistym staje się fakt, iż największa liczba osób korzystających z głosowania on-line to wyborcy młodzi - w przedziale wiekowym 25-34 lata. Jeśli dodać do nich wyborców najmłodszych - od 18 roku życia, wówczas w strukturze wiekowej internetowych wyborców w Estonii dominują uprawnieni w przedziale wiekowym między 18 a 34 rokiem życia. Grupy wiekowe i-wyborców w kolejnych i-wyborach w Estonii zobrazowano na wykresie 2, na podstawie którego wysnuć można wniosek, iż decyzje co do wyboru metody głosowania stoją w dużej korelacji z wiekiem wyborców. Przeciętnie we wszystkich wyborach internetowych głosowało około 40,75\% wyborców poniżej 35 roku życia.

Analizując strukturę wiekową i-wyborców należy zwrócić uwagę, iż wraz z kolejnymi wyborami wielkość grupy powyżej 45 roku życia wykazuje tendencję wzrostową: z 33\% w latach 2005 i 2007 do poziomu 39\% i 37\% w roku 2009. Natomiast wyborcy z grupy wiekowej 35-44 uczestniczą w wyborach internetowych na stałym poziomie - około $24 \%$.

Wykres 2. I-wyborcy według wieku

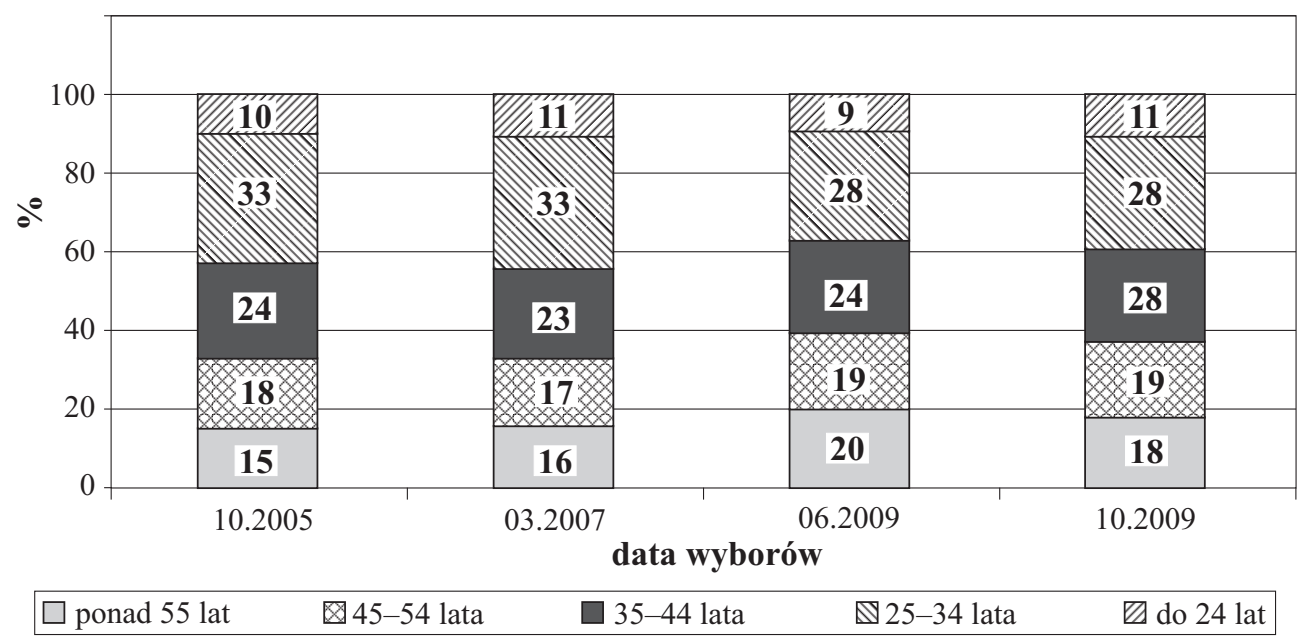

Źródło: Estonian National Electoral Committee, http://www.vvk.ee/index.php?id=11178\&tpl=1062, 10.10.2010.

Bardzo interesujące wnioski formułowane mogą być po uwzględnieniu struktury płci w głosowaniu przez Internet. Analizując udział wyborców internetowych ze względu na płeć widać, że w dwu pierwszych elekcjach w latach 2005 i 2007 udział mężczyzn był większy niż udział wyborców płci żeńskiej. Można to wytłumaczyć tym, iż prawdopodobnie e-głosowanie - jako swego rodzaju nowinka technologiczna - przyciągnęła większą uwagę mężczyzn niż kobiet. Tendencja ta zaczęła się zacierać w kolejnych głosowaniach. W obu rodzajach wyborów w roku 2009 (wybory do PE i do władz lokalnych) udział procentowy kobiet przewyższył udział mężczyzn. Uwzględniając zatem dane z wykresu 3 oraz fakt, iż $53,9 \%$ populacji estońskiej to kobiety, można stwierdzić, iż od 2009 r. nie obserwuje się 
właściwie większych dysproporcji związanych z udziałem przedstawicieli poszczególnych płci w wyborach on-line ${ }^{45}$.

Wykres 3. I-wyborcy według płci

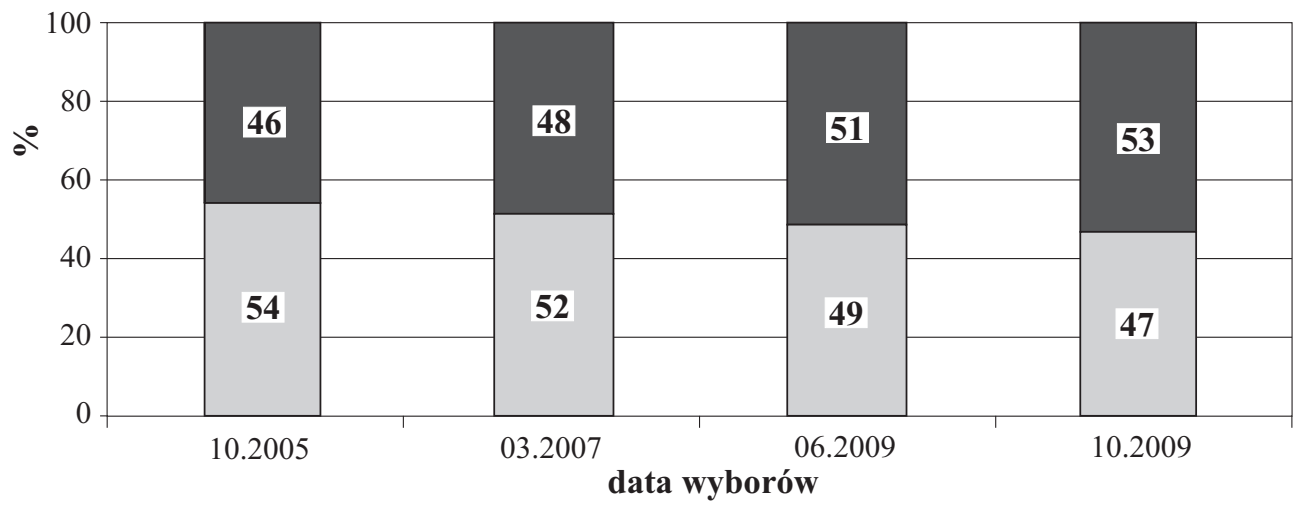

Mężczyźni (\%) $\quad \square$ Kobiety (\%)

Źródło: Estonian National Electoral Committee, http://www.vvk.ee/index.php?id=11178\&tpl=1062, 10.10.2010.

Reasumując, stwierdzić należy, iż estoński model głosowania internetowego pod wieloma względami uznać można za sukces - szczególnie jeśli uwzględni się wykorzystanie $i$-voting przez obywateli i ich udział w głosowaniu elektronicznym.

Władze estońskie twierdzą, że tzw. Remote Internet Voting jest oczekiwaną społecznie, zaakceptowaną cechą procesu wyborczego w tym kraju, która to cecha jest bardzo istotna z punktu widzenia zaangażowania elektoratu ${ }^{46}$. Potwierdzają to dane Estońskiej Komisji Wyborczej - frekwencja w wyborach parlamentarnych wzrosła z 58,2\% w roku 2003 do 61,9\% w roku 2009, a w wyborach do Parlamentu Europejskiego z 26,8\% w 2004 r. do 43,9\% w roku $2009^{47}$. Ponadto, coraz większy udział i-głosów w strukturze wszystkich oddanych głosów w wyborach, potwierdzać może wysoki poziom zaufania społeczeństwa estońskiego do nowych metod wyborczych. Nie zaskakuje przy tym fakt, iż wyborcy, którzy zdecydowali się na głosowanie internetowe szczycą się nieco szerszą wiedzą na temat komputerów czy Internetu. Jak zaznaczono w kanadyjskim raporcie pt. A Comparative Assessment of Electronic Voting, $20 \%$ i-wyborców w roku 2005 stwierdziło, że gdyby nie miało możliwości głosowania internetowego, najprawdopodobniej w ogóle nie uczestniczyłoby w wyborach. W roku 2007 natomiast $11 \%$ zadeklarowało, że prawdopodobnie lub z pewnością nie zagłosowałoby w wyborach, gdyby nie opcja i-głosowania. Dane te wskazują zatem, że możliwość głosowania przez Internet może mieć wpływ na zaangażowanie wyborcze społeczeństwa, szczególnie na aktywność tych, którzy nie uczestniczą zwykle w procedurach wyborczych ${ }^{48}$.

45 A. H. Trechsel, Internet voting..., op. cit., s. 29; Population Statistics, http://estonia.eu/about-estonia/country/population-statistics.html, 10.12.2010.

${ }^{46}$ N. Goodman, J. H. Pammett, J. DeBardeleben, J. Freeland, A Comparative Assessment..., op. cit., s. 35.

${ }^{47}$ Voter turnout data for Estonia, International Institute for Democracy and Electoral Assistance (International IDEA), http://www.idea.int/vt/country_view.cfm?country=EE, 1.12.2010; Estonian National Electoral Committee, http://www.vvk.ee/, 1.12.2010.

${ }^{48}$ N. Goodman, J. H. Pammett, J. DeBardeleben, J. Freeland, A Comparative Assessment..., op. cit., s. 35. 
Warto dodać, iż wiele badań i rankingów na temat e-government oraz społeczeństwa informacyjnego podaje Estonię jako jedno z państw, które odniosło sukces w tej dziedzinie nie tylko w Europie, ale i na świecie. Jako kraj byłego bloku socjalistycznego, Estonia jest często włączana do grona najbogatszych państw w Europie i na świecie - głównie ze względu na rozwój tego państwa w dziedzinie ICT. Warto w tym miejscu zwrócić uwagę na przygotowany przez Organizację Narodów Zjednoczonych Top 35 Countries in the 2008 e-Government Readiness Index, w którym Estonia ulokowana została na 13. miejscu tuż za państwami nordyckimi, Stanami Zjednoczonymi, Japonią czy Szwajcarią ${ }^{49}$. Wynik ten niewątpliwie potwierdza pozycję i sukces Estonii wśród państw, które osiągnęły sukces w dziedzinie nowych technologii i ich zastosowania w życiu publicznym.

\section{Bibliografia}

Barber B. R., Strong Democracy Participatory Politics for a New Age, University of California Press, Berkeley-Los Angeles-London 2003.

Case Study 2: E-Stonia, The Judith and John Bedrosian Center on Governance and the Public Enterprise, University of Southern Kalifornia, http://www.usc.edu/schools/sppd/bedrosian/private/docs/Case_Study_Estonia.pdf.

Democracy.com? Governance in a Networked World, red. E. Kamarck, J. Nye Jr, Hollis Publishing, Hollis 1999.

European Parliament Elections 2004: results, 29.06.2004, EurActiv.com, http://www.euractiv.com/en/elections/european-parliament-elections-2004-results/article-117482.

The European Union and E-Voting. Addressing the European Parliament's Internet Voting Challenge, eds A. H. Trechsel, F. Mendes, Routledge 2005.

E-Voting System. General Overview, Estonian National Electoral Committee, Tallin 2005-2010.

Friedland L. A., Electronic Democracy and the New Citizenship, „Media, Culture \& Society” 1996, vol. 18, nr 2.

Gibson R. K., Internet Voting and the European Parliament elections: problems and prospects, w: The European Union and E-Voting. Addressing the European Parliament's Internet Voting Challenge, eds A. H. Trechsel, F. Mendes, Routledge 2005.

Goodman N., Pammett J. H., DeBardeleben J., Freeland J., A Comparative Assessment of Electronic Voting, Strategic Knowledge Cluster Canada-Europe Transatlantic Dialogue, Carlton University, February 2010, http://www.carleton.ca/europecluster/events/2010-01-26-InternetVotingMaterials/AComparativeAssessmentofInternetVotingFINALFeb19-a.pdf.

Grabowska M., Szawiel T., Budowanie demokracji. Podzialy spoleczne, partie polityczne i społeczeństwo obywatelskie w postkomunistycznej Polsce, PWN, Warszawa 2003.

Grodzka D., E-demokracja, „Infos. Zagadnienia społeczno-gospodarcze”, Biuro Analiz Sejmowych nr 14(61), 16 lipca 2009.

Hagen M., A Typology of Electronic Democracy, 1997, http://www.uni-giessen.de/fb03/vinci/labore/netz/ hag_en.htm.

Horrocks I., Pratchett L., Democracy and New Technology, Electronic Democracy: Central Themes and Issues, http://www.clubofamsterdam.com/contentarticles/Democracy\%20and\%20New\%20Technology.pdf.

Kaczmarczyk A., Czajkowski R., E-Głosowanie-niezbędny element elektronicznej platformy do obstugi procedur demokracji w społeczeństwie informacyjnym, w: Tworzenie mechanizmów i struktur rozwoju elektronicznej gospodarki w Polsce. Warszawa, 12 czerwca 2001 r. Materiały pokonferencyjne, Instytut Logistyki i Magazynowania, Poznań 2001.

${ }^{49}$ United Nations e-Government Survey 2008. From e-Government to Connected Governance, Department of Economic and Social Affairs. Division for Public Administration and Development Management, United Nations, New York 2008, s. 20 (Table 3.1. Top 35 Countries in the 2008 e-Government Readiness Index). 
Keohane R. O., Nye jr J., Power and Interdependence in the Information Age, w: Democracy.com? Governance in a Networked World, red. E. Kamarck, J. Nye Jr, Hollis Publishing, Hollis 1999.

Kitsing M., An Evaluation of E-Government in Estonia, Prepared for delivery at the Internet, Politics and Policy 2010: An Impact Assessment conference at Oxford University, UK, on September 16-17, 2010.

Kotsiopoulos I., Bringing Together and Accelerating eGovernment Research in the EU. eDemocracy Report. Prepared for ICT for Government and Public Services Unit. DG Information Society and Media, European Commission, Brussels.

London S., Teledemocracy vs. Deliberative Democracy: A Comparative Look at Two Models of Public Talk, ,Journal of Interpersonal Computing and Technology" 1995, vol. 3, nr 2, http://www.scottlondon.com/reports/tele.html.

Łapuszek D., Rola postępu technicznego w procesie globalizacji, „Zarządzanie zmianami”, Biuletyn POU, maj 2007, http://www.wsz-pou.edu.pl/biuletyn/?strona=biul_globlap\&nr=6\&p=.

Maaten E., Towards remote e-voting: Estonian case, Elections Departament. Chancellery of the Riigikogu (Parliament), Tallin 2004, Materiały konferencyjne z The International Workshop on Electronic Voting in Europe, Bregenz/Austria, 7-9.07.2004, http://www.e-voting.at/index.php?id=4\&artikelID=62.

Madise Ü., Vinkel P., Maaten E., Internet Voting at the Elections of Local Government Councils on October 2005. Report, Estonian National Electoral Committee, http://www.vvk.ee/public/dok/report2006.pdf.

Musiał-Karg M., Referendum w państwach europejskich. Teoria, praktyka, perspektywy, Wydawnictwo Adam Marszałek, Toruń 2008.

Musiał-Karg M., Technologie informacyjne i komunikacyjne a demokracja. Wykorzystanie Internetu w polityce na przykładzie e-voting, w: W poszukiwaniu modelu demokratycznego, Wydawnictwo Adam Marszałek, red. S. Zyborowicz, Toruń 2009.

Nowina Konopka M., Elektroniczna urna, http://www.rpo.gov.pl/pliki/12066058070.pdf.

Nowina Konopka M., Społeczeństwo informacyjne a teorie demokracji, w: Społeczeństwo informacyjne. Istota. Rozwój. Wyzwania, red. M. Witkowska, K. Cholawa-Sosnowska, WAiP, Warszawa 2006.

Population Statistics, http://estonia.eu/about-estonia/country/population-statistics.html.

Społeczeństwo informacyjne. Istota. Rozwój. Wyzwania, red. M. Witkowska, K. Cholawa-Sosnowska, WAiP, Warszawa 2006.

Stanowisko Stowarzyszenia Internet Society Poland w sprawie głosowania elektronicznego w wyborach powszechnych przyjęte przez Zarzad Stowarzyszenia w dniu 10 stycznia 2007 roku (uchwała Zarządu ISOC Polska nr 2/2007), 11.01.2007, Internet Society Poland, http://www.isoc.org.pl/200701/wybory.

Suski Z., Materiały pomocnicze do wykłady z przedmiotu „Bezpieczeństwo systemów informatycznych”; tytuł wykładu: „Uwierzytelnianie”, http://pjwstk.wafel.com/bsi/BSI-05-uwierzytelnianie.pdf.

Śpiewak P., Obietnice demokracji, Prószyński i S-ka, Warszawa 2004.

Świerczyński Z., Wybrane metody uwierzytelnienia użytkownika sieci komputerowej, Instytut Teleinformatyki i Automatyki WAT, Warszawa, http://www.ita.wat.edu.pl/ zswier/SBS/Uwierzytelnianie.pdf.

Trechsel A. H., Internet voting in the March 2007 Parliamentary Elections in Estonia. Report for the Council of Europe, European Union Democracy Observatory (EUDO), Robert Schuman Centre for Advanced Studies, European University Institute Florence, 31 July 2007.

Tworzenie mechanizmów i struktur rozwoju elektronicznej gospodarki w Polsce. Warszawa, 12 czerwca 2001 r. Materiaty pokonferencyjne, Instytut Logistyki i Magazynowania, Poznań 2001.

Two thirds of households of Estonia have access to the Internet at home, 18.09.2009, Statistics Estonia, http://www.stat.ee/index.php?id=31246\&highlight=internet,connection.

United Nations e-Government Survey 2008. From e-Government to Connected Governance, Department of Economic and Social Affairs. Division for Public Administration and Development Management, United Nations, New York 2008.

Voter turnout data for Estonia, International Institute for Democracy and Electoral Assistance (International IDEA), http://www.idea.int/vt/country_view.cfm?country=EE.

Żukowski A., Dylematy demokracji XXI wieku. Wybory rytualne czy balotaż partycypacyjny?, „Przegląd Politologiczny" 2005, nr 2. 


\section{Summary}

Internet voting in Estonia on the example of the elections in 2005-2009

An increasingly popular tendency can be observed in numerous states in Europe and globally, where modern forms of casting votes are implemented, including, first and foremost, electronic voting via the Internet or mobile telephones. In the opinion of ICT (Information and Communication Technologies) advocates modern civilization is facing an era of electronic democracy, which constitutes this new form of exercising power, based on information and communication tools. Estonia is a European leader in applying electronic voting for election procedures. The paper presents an analysis of Estonia's experience in the field of e-voting in the elections of 2005-2009. 
